\title{
1. Reforming Anglophone public management and governance
}

The starting point is a conundrum: why in the fourth decade of reform to public management and governance have major transformations being sought in Anglophone countries raised the same basic questions that engaged reformers in the 1980s? There are two parts to the problem.

First, major reform has occurred to public sectors, yet official reports suggest that the public service has not changed in significant respects, and new reform agendas keep being launched (see Appendix 1), but generally with mixed results. A number of factors can be advanced for this, but it may be because the conditions for effective implementation of reform are missing or that the public management systems have become irreformable in many respects. Other than hard-edged, structural changes, and blunt-instrument resource cuts other types of innovative reform are often dissipated. The lack of progress in key areas suggests the unlikelihood of durable reform in public management systems which have showed signs of ossification and gridlock for some time.

The second point of departure is the consistently strong indications that governance systems are out of kilter because of the lack of fit and balance between the parts, relationships and capacities. This is displayed in many ways. There is the seeming inability of political executives to get traction on the public service, to handle relationships effectively, and to obtain a results-focus and implement their priorities. Ministers and their advisers continue to exclaim about the public service and the need for reform, yet their own performance and leadership have been wanting and the handling of governance and public policy often ineffectual. There has continued to be rancorous debate about fundamentals that signals lack of agreement between principal actors. The plunging public perceptions of central governments reflect this.

The four systems are prone, to varying degrees to lurch towards instability. This judgement is supported by independent analyses in the four countries that have intensified the level of critique in the 2010s and diagnoses of the dire consequences for good governance of this neglect.

There are a number of factors in play which cannot all be addressed in one book, but which have to be recognised as disrupters to government and reform. There is the moving feast of national and international crises, the implosions of party government and coalitions, ever increasing environmental complexity 
and turbulence, and the impact of technological change and the rise of social media.

This chapter frames the book's approach in terms of the two dominant reform agendas of Australia, Canada, New Zealand and the United Kingdom: managerialism and politicisation. These agenda have different implications for the role and functioning of public management and governance and are in conflict in important respects. The chapter develops an approach to comparing jurisdictions that have been managerialised and politicised and asks why unintended consequences such as bureaucratisation need to be taken into account. It addresses chronic discordant elements and sources of friction as a basis for exploring the consequences of the contradictions and shortfalls in performance.

The longevity of the reform era allows for the examination of the experience of four countries spanning several decades of reforming the system of public management and governance by exploring the results of an extended period of management reform and political change; the consequences, including the long-term impact of political and managerial reform; and what accounts for the results, including the role of the Anglophone model and approach to reform. To engage with the fundamental issues, it is necessary to interrogate fundamental relationships and the reprogramming of politicians' roles, the experiments with managerialism, and the connections between the two.

\section{QUESTIONS ABOUT LONG-TERM REFORM AND GOVERNANCE}

The reform era (commencing around 1980) presented unparalleled opportunities for reformers to learn about what worked and to choose between an ever-increasing range of instruments for pursuing government objectives. Yet there have been continuing questions about experiments (and misadventures) with managerialism and politicisation, what was accomplished, and the lessons to be learned from the experience. Central to this book is an analysis of key dimensions of political and managerial change with an emphasis on the twenty-first century.

The modern era of public sector reform was instigated around four decades ago when Margaret Thatcher enforced political and operational transformation in the United Kingdom. The political dynamics of reform were highly significant as the origins of the reform era were identified with politicians with conviction who aimed to deal with the civil service (Savoie 1994). However, broader questions about the capacity of the centre of government had already emerged and been debated. Management ideas had originated earlier (e.g. Canada, via the United States, in the early 1960s) but no reform initiatives bit into the fabric of public administration in the way that Thatcherism did 
(Campbell and Wilson 1995). The Australian reform agenda surfaced next, but the subsequent entry of New Zealand transfixed thinking about public management internationally (Boston et al. 1996). New theories about organising the state and key relationships flourished, often with an economic basis. These developments produced the realisation that major reform was possible, overturning conventional wisdom about reform failure (Caiden 1991), but was it sustainable and effective?

\section{What has Changed because of Managerial and Political Reform?}

The first dominant change concerns the political executive. Observers in the early 1980s would have difficulty recognising the relationship between the public service and politicians in the 2010s. Basic tenets of the relationship were transformed and often existed in a contested and fragile environment. In the decades between these periods, debate heightened as political executives exploited previously unused powers to direct and influence public management. Their main motives for reform were to assert their authority within the executive branch, to determine what levers targeted political priorities and extract better results from the public service. To achieve these ends a range of political controls and instruments were used. The expansion of executive power led to recurrent questions as to how effective their choices were and with what impact, including whether these actions shattered the existing institutions and foreshadowed the end of Whitehall (e.g. Campbell and Wilson 1995; Page 2010; Diamond 2019b). Similarly, Aucoin's $(2008,2012)$ diagnosis of 'new political governance' was emblematic of an advanced stage of politicisation in the context of the environmental pressures of the twenty-first century.

A management approach was injected rapidly during the 1980s. By the end of the first decade of the reform era, managerialism had been recognised (Pollitt 1990), an Anglophone triumvirate had been identified (Hood 1990) and new public management (NPM) was distinguished (Hood 1991). For another decade, the experiences of and myths about the Anglophone group were highly influential for reform internationally (OECD 1995). Fast forward beyond the NPM variant and the fallout it produced, and the post-global financial crisis (GFC) scrambling to either re-inject NPM elements or renew flagging systems with ailing managerial capability and performance. Governments had to review their public management systems in the 2010s because they were performing poorly in important respects. Repeated attempts at reform had a direct impact when they were rule-based, structural and hard-edged (e.g. privatisation, resource cutbacks), but other management measures were more susceptible to the vagaries of reform contexts, relapses and unintended consequences from pendulum swings and cyclical changes (Pollitt 2008). Consequently, manage- 
ment and political change occurred but not necessarily as expected and hard evidence of the results was often scant (Pollitt 2013b).

\section{What are the Results and Consequences of Sustained Reform?}

The components of executive branches were out of kilter by the 1960s and 1970s. These imbalances encompassed fundamental and unresolved questions about the roles of ministers and public servants, the relative importance of policy and implementation, the mix of centralised control and decentralisation, the roles of administration and management, and the level and form of external engagement; all of which had direct implications for the public management system. A succession of official reports in all four countries produced diagnoses, critiques and recommendations during two decades of review (1960s and 1970s). They were followed by the reform era in the 1980s in which public sectors were redesigned and reconstituted. These diagnoses of the condition of the four systems are a useful counterpoint to the ideological drive of neo-liberalism and new public management. Despite what was claimed, fundamental principles of organisation and public administration were not superseded by the advent of managerialism as some analysts pointed out after the first tranche of reforms (Pollitt 1990; Hood 1998; Gregory 2001).

A central question to ask is, what has become of the public management system over the long term? In the early years the Anglophone countries were acclaimed for the relative ease with which they initiated reforms; however, they subsequently had difficulties sustaining many of them over time. Consider the official reports in Appendix 1, which include references to fundamental issues thought to have been addressed in the 1980s. An outstanding example is the constant search across four decades for methods and techniques that deliver results. Moving from diagnosis to effective and sustained implementation proved to be challenging (twentieth-century implementation issues have been identified in, e.g. Pollitt and Bouckaert 2011; Zifcak 1994). The relapses often signalled a return to confronting the big issues addressed earlier in the reform era: the need to increase control over permanent bureaucrats because they were perceived to be too powerful; and the need to modernise and incentivise bureaucratic decision-making (discussed in the next section).

This apparent loss of the reform achievements and momentum of the 1980s and 1990s can be attributed both to inattention to the governance of the public management system and undue attention as reform agendas swung in diverse directions, the turnover of reforms resulting from new leaders and governments. External factors have also played a part: inter alia economic and political contexts, technological change and management fashions (Pollitt and Bouckaert 2017). The need to adjust and realign with environmental change offered one powerful argument about progressively redefining the state's role: 
'What was critical and possible in . . 1990 is not necessarily vital or possible in 2011' (BPSAG 2011, p. 2; Ryan and Gill 2011; Canada, Clerk of the Privy Council 2013; APS Review 2019).

This leads to a core question of how to account for the mixed results of change over the longer term. At one level, questions can be asked about the relative impacts of managerialism and politicisation. How is it that the gains and potential of the reform era were apparently dissipated by dysfunctions and unintended consequences? Three fundamental tensions exist: how to balance the political executive's demands for responsiveness with inconsistent support for public service competence and capability; how to balance the managerialist ability to utilise a range of instruments with the retention of public service effectiveness; and how to reconcile the contradictions that derive from the interaction of politicisation and managerialism.

This chapter later addresses several factors that can vitiate relationships and the functioning of public management systems. At another level, there are fundamental questions that echo through the history of systemic reform about finding appropriate mixes in the redesign of public management, and balance in the relationships integral to effective governance and policy delivery. Of increasing importance has been whether there has been an understanding of and interest in the condition and sustainability of the public management system.

\section{What is the Role and Continuing Significance of the Anglophone Approach?}

The Anglophone approach refers to both the relationships and conventions of an administrative tradition and a public management model. The four Anglophone countries have been regarded as constituting a coherent group because of their common tradition grounded in the Westminster model, and historical associations and interactions. It has long been maintained that there was an 'Anglo-Saxon' administrative tradition, the term favoured in Europe, that differed from traditions on the Continent and elsewhere (Peters 2003; Rhodes et al. 2009; Painter and Peters 2010a).

The coherence of the tradition appeared to be reaffirmed once the reform era was underway as few other countries could respond so directly and quickly. The emergence of a distinctive pattern of public management reforms and the commonalities between the countries confirmed a connection between the administrative tradition and an Anglophone reform model. Australia, New Zealand and the United Kingdom were the countries most identified with major change in the initial decades of the reform era, and they acquired a reputation for being significant reformers and leaders of the public management movement (Pollitt 1993; OECD 1995), and a source of reform experience that 
was diffused internationally (Halligan 2015c). Questions about the efficacy and sustainability of reform in these countries point to the need to examine the role of the tradition, and its associated model.

First is the question of how well features of the Anglophone reform model relate to the tradition. The Anglophone reformist agenda has been comprehensive, continual and iterative, and reliant on using a range of public and private instruments, enabled by managerialism. The administrative tradition plays a role in reform because it is both facilitative, enabling instrumentalism while also constraining reform in some respects. The logics of rational action and appropriateness can be seen to be in play here (March and Olsen 1989).

Secondly, the assumption that the four countries are part of one tradition suggests the need to demonstrate the extent to which they operate within and engage with it through comparisons across political, managerial and governance dimensions. There are distinctive elements to their historic pathways (see Chapter 2), which might suggest divergence and a loosely coupled tradition, but the strength of the core principles and reform dynamics might still produce adherence to a common tradition. Other state traditions have exhibited variations between countries (cf. Veggeland 2007; Ongaro 2009; Lægreid and Rykkja 2015), the implications being that if the influence of country contexts is strong, several public management models could be apparent.

Thirdly, there is the question of whether the tradition has been 'reconstituted' or modified (Richards 2008; Rhodes et al. 2009). Given the level of changes, to what extent has reform remained true to Westminster principles and maintained something distinctively Anglophonic? The internationalisation of reform has led to commonalities in approaches to public management, which suggests the need to compare countries operating under different traditions to establish whether traditions retain distinctiveness.

Finally, there is the question of the significance of the Anglophone model and its public management approach over the long term. It has long been apparent that Anglophone countries are not necessarily at the forefront of international reform as their performance is less prominent in international rankings (e.g. the UK is no longer the model: King and Crewe 2014, p. ix). Other, usually small, often northern European countries have acquired that status in international benchmarking exercises.

\section{FRAMING THE ANALYSIS}

Three big ideas dominated the outset of public sector reform: traditional bureaucracy had failed because it was no longer suitable for the current environment; managerialism was the alternative, the new paradigm for achieving public purposes; and elected politicians were responsible and should lead, 
direct and control. The latter two ideas are fundamental to reconfiguring the public management system.

The lack of frameworks for analysing reform led observers to draw on general analyses of public administration that delineated major components that were subject to change. Several arenas of 'behaviour and belief' have been distinguished, each associated with an agenda (Self 1978, pp. 313-14; Pierre 1995). Categories for demarcating the analysis of major changes to public sectors include the bureaucratic, political, social and private sectors. The latter two focus on external relationships between a bureaucracy and its environment; the first two are fundamental to a system of government. The two internal agendas reconstitute the bureaucracy and redefine the political executive's role, both of which are the focus of this study.

These types of analysis were salient to the traditional model of public administration and its modern successor in so far as the latter was a response to the limitations of the former. Traditional public administration (TPA) held sway in Anglo-American countries from the nineteenth century to after the Second World War and was grounded in explicit distinctions between the public and private sectors, and between politicians and civil servants (Garvey 1993; Hood 1994), the latter being delegated responsibilities for implementation as per the classic conception and accorded discretion to use their expertise (Garvey 1993). The bureaucratic agency was a largely bounded organisation that operated according to principles that in many material respects reflected Weber's depiction of an ideal bureaucratic type, in particular specialisation, hierarchy and formal rules.

In an era of unprecedented reforms since the 1980s, two fundamental questions of public management and governance have featured and emphatically shaped the design of the public management system. These questions are interconnected in that they both represent an assault on existing notions of bureaucracy and relationships within the executive branch and challenge the Westminster system. The first question centres on the role of executive government in the state, and how it operates in terms of Westminster principles in Anglophone countries and institutionalised understandings about the roles of politicians and bureaucrats. A central dimension is the relationship between democracy and bureaucracy and the complexities that this entailed (Etzioni-Halevy 1983). The lineage of how this relationship should be redefined was articulated through 'responsiveness' and the assertion of the authority of representative government and received expression through rational choice theory. These ideas represented a swing away from the conventional wisdom of the 'administrative state', and from trustee perspectives on bureaucratic roles. The second set of ideas is about moving beyond bureaucracy as it had been experienced (Barzelay 1992; Halligan and Power 1992), and its associated features. At its core was the promotion of managerial over adminis- 
trative principles associated with TPA as advocated by proponents of generic management. A set of features associated with traditional bureaucracy (e.g. the focus on process) were replaced by a new set (e.g. the focus on results). A strong underpinning was offered by private sector experience, which was echoed in the erosion of the differentiation between the two sectors.

Each approach pointed to distinctive ways for developing the public management system. The first reinforced hierarchy by substituting one form of control for another - a top-down political direction for bureaucratic processes. The second sought to release the system from the constraints, boundaries and operational modes of traditional bureaucracy, but subjected it to management precepts as well as the mania of managerialism. Both opened the system by freeing it from the limitations of traditional principles and boundaries and exposing it more directly to a range of environmental influences, the fashions of generic and private management, and the dogma and vicissitudes of politics. In several respects the public management system was now the obverse of its predecessor, presenting both perennial and new tensions and dilemmas.

The focus of this book is the analysis of the longer-term impact of managerialism and politicisation and the consequences of a political management approach based on the combination of the two (Halligan and Power 1992). The literature has addressed the initial impact of reform, but much less so the second half of the reform era (with the turn of the century serving as an approximate transition point). The issues emerging from the changes have continued to reverberate in the twenty-first century, questioning the purpose of a public management system once seen as the stable element that supported the dynamism of politicians; and asking whether an appropriate balance and fit could be developed and sustained through roles and relationships.

\section{Politicising the Executive Branch}

Under the Westminster model, relations between politicians and bureaucrats traditionally centred on the co-existence of the neutral public service and responsible government (Aucoin 1995). The embedded tension between the two elements was kept in balance by applying well-established principles, but their enactment had become dependent upon the overarching role acquired by permanent secretaries (i.e. heads of public service departments). By the beginning of the reform era, this type of relationship could no longer be assumed and was being challenged.

During the last 40 years, a new imbalance became characteristic as politicians expanded their authority over the previously ascendant officials. The relationship between the political executive and the public service changed independently of management reform, although the two were interlinked. The origins of the revolt against an entrenched public service long predated the 
reform era and was foreshadowed in the United States with the move away from progressive values by more assertive political executives and political appointments to the civil service following the Second World War. Canada's Prime Minister Trudeau initiated changes to the core executive that presaged the 'new political governance' (Aucoin 2006).

There has been extensive discussion of what constitutes politicisation (e.g. Mulgan 1998; Peters and Pierre 2004a, 2004b). In this study, politicisation refers to extensions to the political executive's influence and control within the executive branch. The usage here has been chosen for its simplicity and its inclusiveness (cf. Kemp 1986). It focuses on the use of ministerial levers for increasing political influence, and resources and changing relationships. The expansion and contraction of political roles are normal in governance over time, and ministers are constitutionally empowered to exercise authority.

The modes of demarcating politics and administration range from a model that firmly separates political and public service careers to that in which the careers intermingle and boundaries are weak (Pierre 1995, p. 207). The relative independence of the political and bureaucratic spheres has meant that the apolitical British model could once be represented as being at one end of an international spectrum that envisaged a heavily 'politicised' system (mainly political appointments) at the opposite end. A set of issues for the reform era was whether, to what extent and in what respects, systems were moving along this spectrum, and what the impact was on effectiveness of relationships and the performance of the public management system.

A traditional relationship is based on well-understood norms: a neutral public service that serves the political executive regardless of party, and a political executive that in turn respects the integrity of the civil service by supporting its apolitical and professional character. Specific features are the career public servant, a permanent official who survives successive governments; senior appointments drawn from the ranks of professional careerists; and the ministerial department as the repository of expert knowledge and primary policy adviser to government (Roberts 1987; Aucoin 1995; Campbell and Wilson 1995; Halligan 2001). The contrasting features of the responsiveness model have important implications for the operation of the political-administrative system because it is no longer a relatively closed and stable system underpinned by a general understanding of roles. Instead, the political executive seeks to secure and sustain its control over the public service. There are various interpretations of the direction of the relationships internationally with generic 'politicisation' being favoured by observers (Peters and Pierre 2001, 2004a).

How can politicisation be conceptualised and analysed? Principal-agent theory provides a distinct alternative to traditional formulations emphasising the administrative state and guardian roles. The shift from a trustee to an agency conception is one basis for analysing changes to the relationship. 
Table 1.1 Instruments for expanding ministerial influence

\begin{tabular}{ll}
\hline PM/Minister's levers & Potential extension \\
\hline - Prime minister & Prime minister's office. \\
• Ministers' roles & PM's dept centralising role. PMD delivery/results unit. \\
& Principal-agent: range of roles, authority, responsiveness. \\
- Ministers' offices; partisan staff & Roles in policy processes and management. \\
• Policy advice & Pluralisation of roles in policy development. \\
- Management roles & Implementation. \\
- Appointments & Senior appointments; performance assessment of officials. \\
\hline
\end{tabular}

Agency theory is of value for drawing attention to ministers' attempts to reduce information asymmetries and to seek control of the public service and the results of its work (Laffin 1997). For the political executive, the means of changing the basis of the relationship is through managing the incentives faced by public servants. Under a rational choice approach, the incentive structure for an actor involves the costs and benefits in making choices (Ritchie 2014). For a politicising agenda, the question is how public servants' incentives can be reshaped to suit ministers.

The incentives for public servants to respond derive from ministers exercising ministerial authority (and through partisan agents operating as extensions to that authority). The analysis of politicisation is based on the extent to, and ways in, which political instruments are employed (Table 1.1). The relative use of these instruments in different countries provides a means for making comparisons about modes of politicisation. The expanded bevy of instruments applies also to a range of processes, such as coordination, performance and implementation examined in later chapters.

\section{Managerialism}

The conception of managerialism used in this book assumes a set of core features that are present in some form. Managerialism is favoured over NPM because it is a more focused concept and does not carry the same baggage. It was in fact a forerunner of NPM (Pollitt 1990, 1993), and an older and more diverse movement (Painter 2011). It was the preferred term in Australia (Considine and Painter 1997; Halligan 2007b; Painter 2011); and Canada

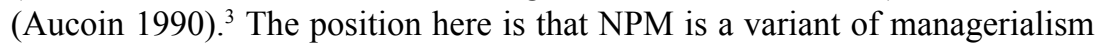
(Pollitt 2016).

Management evolution occurs because of the ability to incorporate new approaches, and to refine old ones, although they may be vulnerable to transient fashions and agendas. Specific components may be elaborated (performance, agencification), or externalised (e.g. outsourcing), recalibrated internally 
(horizontal management), or invested with specific meanings (values management), but the managerial centrepiece provides the continuity. For most authors previously mentioned, managerialism is the core concept, and rather than being distracted by NPM (or new public governance), all iterations are depicted as variations on managerialism.

The conception of managerialism has several components, not all of which can be addressed in this study. Prominent features, such as efficiency and resource use, are central objectives (and prevail over other objectives when austerity is prominent) but have been examined (by e.g. Hood and Dixon 2015). The attributes most relevant to this study are:

1. Management processes are central to the functioning of the public management system but depend on improved managerial capacity for delivering results and services, and this is contingent on allowing managers to manage.

2. Improved performance and results are fundamental and underscore expectations of managers.

3. Discretion via forms of decentralisation: 'devolution' of responsibilities to departments; delegation to managers allowing them line authority over resources; and disaggregation of departmental responsibilities through agencification. It addresses one of two principles of TPA, generalised rules, and their replacement by managerial discretion (or flexibility and freedom to manage) (Dunleavy and Hood 1994; Hood 1994).

4. Change and reform. Managerialism emphasises change because of its receptivity to new techniques and responsiveness to environmental change, a distinguishing feature being 'flexibility ... in absorbing or generating new ideas and models' (Painter 2011, p. 238). Change management and management improvement are priorities because of the acceptance of the ethos of continuous change. System design and reform are constant features.

5. Managerialism was conceived in terms of debureaucratisation (Savoie 1994), the removal of features associated with rigid forms of organisation. To what extent bureaucratic features were reinvented as part of the controls of a new management system (Gregory 2001) for the imperatives of managerialism required measuring, evaluating and rationalising (Hoggett 1997).

Managerialism was also superimposed on an existing TPA system and the extent to which the old was replaced by the new was an open question (Halligan and Power 1992) and depended on whether functional specialisation, hierarchy and the reliance on rules could be addressed. There was extensive choice and flexibility in steering, which encompassed a range of instruments 
for organising and controlling public management, including structures, delivery options, performance and coordinating.

In addition to managerialism (about changing internal operations) and politicisation (about changing relationships and authority), there have been two contenders for greater attention that highlight external relationships: NPM has focused on transferring responsibilities to external agents, and is closely associated with reducing the role of the state; and new public governance relies on networks that extend (or exist) beyond the boundaries of government. Both cover activity outside the scope of this study at least in terms of systematic analysis, although externalising agendas have had major effects on internal competence and can be touched on by drawing on a recent study (Craft and Halligan 2020).

New public management (NPM) has of course been influential. Several features distinguish it from managerialism, most importantly a mainstream view that NPM, 'fundamentally espouses economic values and objectives' (Christensen and Lægreid 2011a, p. 3; Halligan 2011b) and the minimisation of public-private distinctions. At the time it was coined, NPM was informed more by developments in New Zealand and the United Kingdom than Australia (Hood 1990). An NPM approach entails inter alia externalisation, marketisation, privatisation and competition, as well as disaggregation (e.g. Hood 1991; Lane 2000), but many applications of NPM inflated it to be a catch-all that encompassed anything that happened. These features remain as options rather than core operating principles of the public management system.

Another set of ideas, variously known as 'new public governance', 'governance' or 'network governance', has been recognised as addressing the limitations of other models (Osborne 2010; Pollitt and Bouckaert 2017). A further approach, also hailed as a likely successor of NPM, is 'public value governance' (Bryson et al. 2015), which has the advantage of encapsulating public governance dimensions while bringing into relief public value. The emphasis on engaging non-government actors and networks is arguably most relevant to the sub-national level, although the pressures on central governments to engage externally have been increasing (Prince 2018). But note the contrary argument that traditional governance has decreased at the centre in Britain with less consultation and an 'impositional policy style' (Richardson 2018). The centrality of the state continues (Bell and Hindmoor 2009) and may increase under governments exploiting the plenitude of power. Nevertheless, the underlying principles have resonance: a focus on the horizontal rather than the vertical, and incorporation of a broader range of actors and voices in the policy process. Much of the twenty-first century reform agenda was rotated to address joining and coordinating increasingly fragmented government. Public governance complements and extends the repertoire of management (cf. Hyndman and Liguori 2016). Public governance is employed here in the 
sense of governing the public management system and specifically horizontal collaboration and networks within the system.

Where is managerialism located in the overall approaches and models that have proliferated? One response is to use hybridity as a means of capturing the 'layers' or contradictory dimensions of public management systems (Christensen and Lægreid 2011c). There are several reasons for adopting a different approach if hybridity applies to broad brush approaches. First, at their core the public management systems of Anglophone countries adhere to managerialist principles. Secondly, the argument that there is a progression through models, which naturally leads to new public governance, has yet to be established (although it is more apparent at the delivery end where substantial interaction with third parties is required). Specifically, there is a lack of evidence for NPM being transitional between TPA and new public governance (Hyndman and Liguori 2016). In addition, the significance of the new digital era is unmistakable (Dunleavy et al. 2006), but less as a successor to public management than a major overlay. Thirdly, a neo-Weberian option is advanced (Pollitt and Bouckaert 2011, 2017), because of its relevance to European countries, but is normally grounded in a different administrative tradition and adaptation of Weberian principles.

The position here is that public management systems in Anglophone systems are anchored in managerialism as defined, but to varying degrees other nominal (quasi-) paradigms are either absorbed or constitute periodically prominent elements with the potential to influence its character. Public management became the mainstream with variations (notably TPA, NPM, digital governance and public value governance) encompassed by it. Other tropes can also be subsumed within a public management approach, and in that sense the public management model is more complex and hybrid (Allen and Eppel 2017). It is important to emphasise at this point that the incorporation and significance of managerial and other dimensions varies among the four country systems.

\section{INTERPRETING LONG-TERM IMPACTS}

Just as policy reversal is a product of internal decay and external pressures (changes in ideas, interests and environments), it can be represented as a hybrid of these factors (Hood 1994, pp. 4, 16). In seeking to interpret the condition of Anglophone systems in the long term four questions are addressed. Apart from the effects of managerialism and politicisation, their co-existence has consequences which are incompatible. A second focus is the impact of the changing environment on the behaviour of political executives, a syndrome christened 'new political governance' (NPG) by Aucoin (2012), and which reverberates within the public management system. Thirdly, an administrative tradition 
interpretation examines the tensions between the precept of enabling change (arguably more salient than countries from other traditions) and constraining departures from conventions. Finally, constant change can be a result of internal dynamics (the managerialist's compulsion to change and the politicians' inclination to press against boundaries and conventions) and movement in the external environment, but there is a broader literature on the role of cycles, which offers insights on long-term patterns (Pollitt 2008).

\section{Managerialism and Politicisation: Complementary and Competing}

Managerialism and politicisation derive from different sets of ideas. The combination of the two has had powerful and far-reaching implications for the public management system. Operating together they may be mutually reinforcing. But they are also susceptible to intractable tensions for they reflect different sets of principles, one primarily about political control, the other about management autonomy. This is explicit in Aucoin's argument about two strongly etched paradigms (reflecting public choice theory and managerialism) that support different organisational principles based on incompatible premises (Aucoin 1990; cf. Pollitt and Bouckaert 2017). One is essentially about centralisation and political authority, the other about decentralisation and management authority and autonomy. Because of the internal contradictions of managerialism these two are often in competition or conflict.

This representation needs to be qualified because applications are mediated by the administrative tradition and country contexts. Centralisation is not the sole preserve of the political executive, and decentralisation may aid ministerial roles. Managerialism is a fusion of ideas that has continued to evolve (Pollitt 1993) and which is not necessarily consistent in practice (Gregory 2001). The point to be underscored here is that there are contradictions within managerialism, the internal inconsistencies meaning that central control and management autonomy must somehow co-exist.

Four dilemmas that arise in government organisation are control and autonomy, contrasting role conceptions, internal and external capacity and structures, and stability and change. In each case the dilemma arises from how to reconcile the arguments of opposed positions.

\section{Control and autonomy}

The question of control within the public management system and the discretionary provisions covered are central to a range of issues. One articulation of the 'bureaucracy problem' points to potentially irreconcilable conflicts between two paradigms where they co-exist because public servants are unclear about how to operate due to different perceptions of the problem. Politicians seek to tame bureaucrats by concentrating power in the political 
executive. In contrast, under the managerialist paradigm excessive controls over bureaucratic behaviour are unacceptable because they reflect the incentives under traditional bureaucracy that produce administration by rules and regulations rather than by results (Aucoin 1990). How is control handled under the combination of managerialism and politicisation? What do politicians' controls mean for managerial autonomy?

There is a broader question about the exercise of discretion and how it is constrained, which applies to both politicians and public servants (Garvey 1993). The dilemma derives from levels of discretion and how they might be counterbalanced. Bureaucracy produces a dilemma for democracy if it becomes too independent and powerful, thereby posing a threat to the political executive. However, bureaucratic independence is indispensable for preventing political malfeasance and safeguarding democratic procedures (Etzioni-Halevy, 1983).

\section{Agency, stewardship and trustee perspectives}

The role conceptions adopted by political executives in their relationships with public servants are central. The dominance of principal-agent theory has meant a huge investment in agents who are responsive to political executives and a reinterpretation of the role of the public service. The primary objective is securing this responsiveness by employing incentives (Knott and Miller 2008). Contrariwise trustee theory envisages that the public interest is best ensured over the long term through insulating specified responsibilities from the short-term interests of politicians by assigning them to public agencies. The problem is determining constraints on bureaucratic discretion.

Two alternative perspectives have gained currency. A refocus on the virtues of bureaucratic discretion is based in part on the argument that the main organisation problem is not the moral hazard of the agent but that of the principal. This can be seen as a re-statement of the argument for delegating responsibilities to trustees, which is argued to be a factor in democratic success (Miller and Whitford 2016). The alternative stewardship perspective entails demarcating responsibilities for senior public servants with a focus on the public interest and the long term. Central questions are whether to and how to incorporate these perspectives in the public management system.

How are spheres of responsibility delineated for policy and management? If the 'public choice paradigm' is integral then the emphasis is on the top-down role of political executives. If ministers function as policy managers, those who serve them operate as agents and cannot "function as independent "experts" with discretion to counter the will of their political "managers or "masters"" (Aucoin 1990, p. 127). Partisan actors may pervade policy and management, which either dissipates a division of roles between politicians and bureaucrats other than command and control or imbues it with ambiguity. 
There have been predictions for three decades of the potentially negative effects of the assertion of ministerial authority and the expansion of the political realm (Campbell and Wilson 1995), particularly where ministers' actions are unbridled and arbitrary and political controls relentless. Increasing politicisation has challenging implications for the institutions of government if the constraints on excessive discretion are relaxed or ignored.

\section{Capacity of the state}

Managerialism allows flexibility and choice in ways for achieving objectives, which can be wide-ranging. Capabilities may be sourced from internal and external actors. The use of third parties for the provision of services is a significant thread of debureaucratisation. Politicians may regard the private sector as the first choice where it has the capacity to provide services, thus reducing the role of the state. The twentieth-century use of contracting out and using external agents for service delivery are beyond the scope of this study but are related to the five features identified above. However, where the provision of capacity relies on extensive use of different actors because of the loss of expertise, the externalisation of management capacity impacts on internal capacity as anticipated earlier. The department is expected to be able to respond to ministers' needs and priorities as required but confronts the problem of maintaining internal capability where externalisation is prominent. The dilemma centres therefore on the question of balance between external and internal capacity.

\section{Stability and change}

An accepted principle of government has been the provision for both stability and change. Three questions are significant. The first concerns the dominant ethos of managerialism: the commitment to change and responsiveness. The second concerns the standing of the public service and whether it is owned by a government or is an institution in its own right that serves a succession of governments. This is the crux of a set of tensions that have bedevilled Westminster systems, which have a constitutional basis, and arise in the next chapter and subsequently. The third dimension relates to the roles of politicians and bureaucracy. Under the traditional system, a distinction has been drawn between the dynamic element (politicians subject to turnover) and the stable component (the permanent bureaucracy) (Aberbach et al. 1981). Traditional bureaucracy, which was relatively pragmatic and instrumental following the Anglophone tradition, had the ability to change, but boundaries insulated it from external and internal influences and the ethos was not one of responsiveness and continuous improvement. In contrast, managerialism is attuned to change, adjusting techniques as appropriate, and the intensely instrumental focus offers flexibilities and options. But this dynamism aligns it with the political cycle rather than offering a counterbalance. 


\section{Change and Cycles}

Patterns of change over time can be analysed through different reform stages, and there is a substantial literature that adopts that format (e.g. Christensen and Lægreid 2006; Dunleavy et al. 2006; Richards and Smith 2006; Halligan 2007b). Rather less attention has been given to twenty-first-century stages because the patterns appeared to fade with less distinct indicators that can be linked to reform models. A sense of progression was also lost with the recycling of reform types (e.g. NPM) and layering and sedimentation offered an alternative interpretation (Christensen and Lægreid 2011c).

The role of cycles in public management provides one type of interpretation of change dynamics (Pollitt 2008). Public organisations are dynamic and undergo constant changes, particularly where a premium is placed on environmental responsiveness. Organisations must attend to a range of problems, which can be defined in basic terms, such as technical, political, and cultural (Tichy 1980). These problems are ongoing and require adjustments at different points, which can be conceptualised in cyclical terms producing separate cycles (i.e. technical, political and cultural adjustment). However, organisations vary in their investments in undertaking adjustments in each cycle (Tichy 1980, p. 165; Pollitt 2008). The several types of management addressed in Chapter 4 can be associated with separate cycles. Most importantly for this study, political and managerial agendas operate on parallel cycles that can often be in sync, but frequently are not. Recognition of the role of pendulums, e.g. centralisation and decentralisation pre-date the reform era (Spann 1981), but radical reforms that are highly centralised (rigid and impervious), decentralised (problems with coordination and steering) or politicised can be expected to produce a response of similar intensity.

A second view is of the longer term and the role of institutional aging both of the political realm, and managerialism. An exploration of the middle age of managerialism at the mid-point in the reform era inquired whether there was movement into an age of paradox (Hood and Peters 2004). In the twenty-first century what indicators are available on the condition of public management systems? The ossification of traditional public administration and excessive bureaucratisation were well established (Caiden 1991), yet unintended effects were apparent in the early decades of managerialism (Hood and Peters 2004). Other indicators of the aging process are also available: aversion to risk taking, rule encrustation, routinisation and burgeoning procedural rules and 'mutation-based discretion' (Garvey 1993, pp. 188-92). Regardless of an ageist judgement, the key point to note is that evidence of systemic changes in the use of rules, regulation and red tape is likely to signify some broader condition of the public management system. 


\section{THE ARGUMENT AND APPROACH OF THE BOOK}

The condition of Anglophone public management and reforms has been closely observed, but there are few systematic and comparative treatments of them in the twenty-first century. European countries have been the subject of comparative studies (e.g. Ongaro 2009 on Napoleonic countries; Greve et al. 2016 on Nordic countries; Van der Meer et al. 2015 and Hammerschmid et al. 2016 on reforms in Europe). OECD countries are covered in editions of Pollitt and Bouckaert $(2011,2017)$. There have also been individual country studies that illuminate public management in Australia (Edwards et al. 2012); Canada (Aucoin et al. 2013; Thomas 2014; Savoie 2015a); New Zealand (Boston 2017); the United Kingdom (e.g. Campbell and Wilson 1995; Richards 2008; Rhodes 2011; Dunleavy and Carrera 2013; Diamond 2014, 2019b; Hood and Dixon 2015). Analyses of major issues are also relevant: coordination (Bouckaert et al. 2010), new public management (Christensen and Lægreid 2011a), digital era governance (Dunleavy et al. 2006; Clarke 2019), new political governance (Aucoin 2012), political system reform (Raadschelders and Bemelmans-Videc 2015), governing for the future (Boston 2016, 2017), and comparing Westminster systems more generally (Rhodes et al. 2009; Weller 2018).

Overall, the literature on Anglophone countries as a group is incomplete, lacks a comparative dimension (but see Maor 1999; Rhodes et al. 2009), and does not engage with major issues over the long term. More specifically, the separate and combined effects of managerialism and politicisation have been neglected (but see Pollitt and Bouckaert 2017). The limitations in the treatment of topics central to this study may derive from sub-disciplinary specialisations and too few attempts to incorporate separate literatures. This book draws on both public management and the executive politics literature (e.g. Lodge and Wegrich 2012; Pollitt and Bouckaert 2017) and recognises that the 'partisan-political' dimensions of policy-making exposed in the recent advisory literature has been insufficiently addressed in mainstream studies (Craft 2015).

The book covers the central governments of Australia, Canada, New Zealand and the United Kingdom, and how political executives in these countries, particularly in the second half of the reform era, have sought to rework their public management systems to suit political agendas and environmental pressures. This focus means that neither the Australian states and Canadian provinces nor the 'four-nation governance' (Burnham and Horton 2013) of the United Kingdom feature in discussion. The choice of countries derives from their common adherence to an Anglophone tradition and their early and continuing commitment to public management reform. There are several striking 
differences among them, reflecting contexts and responses to pressures for change: the type of early engagement with managerialism, and the nature of the enthronement of the political executive, being prominent.

The study is both comparative and historical. Several dimensions of executive branches are examined over time and across the four countries. The comparative analysis focuses on politicisation and managerialism and elements thereof. It is informed by historical institutionalism because of the emphasis on long-term patterns and the role of traditions, structures and institutions (Pollitt $2008,2013 b)$. The relationship between stability and change is central, as is how the patterns are frequently punctuated by reforms. The role of political leaders in initiating and driving change in the executive branch is a strong current, although the study does not systematically explore the interaction of structure and agency.

The study draws on extensive interviews with public servants, present and former, in central agencies and departments, and with think tanks, overseas agencies and academic observers. These occurred over a decade or more in the capital cities of the four countries but were concentrated in 2016-18. Secondary sources encompass public documents, both official reviews and reports (which can be candid, if circumspect, with regard to details) about the state of public management - and independent analyses by audit offices, parliamentary committees and other government agencies, as well as think tanks and other experts. The rationale for the extensive use of document analysis in qualitative research has been made (Bowen 2009) and used with good effect in relevant studies (Pollitt 2012). The consilience method involves combining evidence from numerous different sources, which together provide a strong evidential basis for the analysis (Hood and Dixon 2015; Matthews 2016). The main characterisations are not tied to a specific time or government. This is a late 2010 s study with analysis focusing on the twenty-first century but extending back to the early reform era as appropriate.

\section{Argument and Structure}

The fundamental issues about the constitution and operation of a public management system comprise core questions of traditional public administration, and new questions that arise from the results of extensive political and managerial reform. First, the analysis of the political-administrative relationship addresses the changing roles of both the political executive and the public service, and how their relationships are now conceived and operate. The impact of politicisation features in all chapters. The second dimension focuses on management processes as a means of tracking through managerialism. These processes are examined in terms of the devolution of responsibilities, capability and capacity, core components of managerialism, such as perfor- 
mance management, and the continuing focus on results. The third dimension is the governance of the public management system, which considers institutions integral to the executive and the maintenance of understandings about the Westminster model and coordination within the public management system.

Recurrent themes within the book are the meaning of these reforms for the Anglophone administrative tradition; how the tradition constrains initiatives and facilitates reform; and the extent to which the tradition can accommodate variations and still remain distinctive. Diversity within the tradition and the associated public management model means that generalisations about trends and patterns apply more clearly to some countries. In terms of comparing public management systems, the working assumption is that similarities will be pronounced because of the shared administrative tradition. However, the differences will provide explanations for variations among countries, such as structures (e.g. the federal/unitary distinction) or in context choices (e.g. level of managerialism and the use of political controls). The four countries are compared across indicators for managerialism and politicisation, and the relative importance of instruments for specific purposes.

The structure of the book moves from the contexts of cultural and historical reform to the political and managerial dimensions with a macro-level focus on coordinating the public management system, then providing more holistic perspectives on the public management system. The framework for the book is centred on managerialism and politicisation, the two separate but often interdependent agenda that launched the reform era.

The examination of the Anglophone administrative tradition (Chapter 2) addresses its distinctive features, and how it is differentiated from other traditions. The question of how a distinctive model(s) of public management has become identified with countries in this tradition, and how it compares, is also addressed. Country patterns of change in the reform era are outlined in Appendices 2 and 3.

The following two chapters analyse the redistribution of roles and power between the political executive and the public service. Chapter 3 explores the expansion and strengthening of the political executive in all four systems. Chapter 4 examines the effect on senior appointments in the public service of the changing dynamics of the relationship between politicians and senior bureaucrats.

Managerialism is addressed in Chapters 5 and 6. Chapter 5 examines the fluctuating fortunes of key management processes and precepts, and the implications for capability and management improvement. The central question of performance and results is considered in Chapter 6. The redux of bureaucracy in a management and political milieu is the subject of Chapter 7, and the impact of excessive regulation on attaining objectives. Different forms of coordination are examined in Chapter 8, focusing on how instruments have 
changed, and the relative importance of political control, the vertical and horizontal axes and collaboration.

Chapter 9 pulls together the strands of the book, revisits the core questions and addresses the implications, including unresolved issues, which are fundamental to the functioning and condition of the public management system. These include the implacable problems that arise unless there is careful attention to system imbalances that inevitably become endemic where political priorities dominate. The long-term impact of reform over more than three decades is analysed by examining the condition of public management in the 2010s, the impact of managerialism and politicisation, the lessons and implications of the reform era, and the condition of the Anglophone tradition. Chapter 10 (a postscript) addresses agendas and scenarios for the four systems.

\section{NOTES}

1. The term Anglophone tradition is preferred to the broader Westminster model (see Marsh's 2011 formulation), although the latter is used where appropriate. 'Anglo-American' is a broader conception of the Anglophone group (Halligan 2003a).

2 Other politicising instruments are available, including board appointments of statutory authorities, and pressures on agencies normally thought to be beyond political interference.

3. A variation was managerialism as one of four models of NPM (Barzelay 2002). Definitions of managerialism also vary (e.g. Barzelay 2001, pp. 183-4). Compare 'neo-liberal managerialism' and the clumsy 'post-NPM managerialism' (Painter 2011, p. 248).

4. Delivery failure was a primary driver of original reform in Australia. It later become more prominent across the systems (1990s), and UK-inspired deliverology became a fad in Canada in 2016.

5. One expression, 'mix and match', suggests how ministers (and public managers) could make calculations that include internal and external options. For an expression of this, see Taylor (2008). Market design and related ideas extended the external options, although the focus here is internal instruments.

6. The broader complexities are captured through Etzioni-Halevy's second dilemma. Democracy creates a dilemma for bureaucracy because the 'rules are self-contradictory and put bureaucracy in a double bind ... to be both independent and subservient, both responsible for its own actions and subject to ministerial responsibility, both politicised and non-politicised' (Etzioni-Halevy 1983, p. 87).

4. The transience of political leadership in the 2010s meant that relating the study to specific governments would have been problematic, e.g. Abbott, Gillard, Rudd and Turnbull (Australia); Martin, Harper and Trudeau (Canada); English (New Zealand); and Brown and May (United Kingdom). 